\title{
ELT Teacher Trainees' Attitudes Towards Environmental Education And Their Tendency To Use It In The Language Classroom
}

Esim Gürsoy, Uludağ University, Turkey Gülderen T. Sağlam, Uludă̆ University, Turkey

\begin{abstract}
With the change of focus in language teaching from grammar-based approaches to more communicative approaches, contextual language learning gained importance and found body in the English Language classroom. Global issues constitute one of the most popular contexts for purposeful language learning and meaningful language use. Increasing number of ELT (English Language Teaching) course books involve global issues in their content. Within the scope of socially responsible teaching (SRT) it is believed that it is the teachers' responsibility to help their learners develop awareness on these issues. From this perspective current research aims to shed some light into ELT teacher education process by investigating teacher trainees' attitudes and tendencies towards environmental education and their inclusion in the ELT lessons. Data for the research is collected from 224 third year ELT teacher trainees via a questionnaire prepared by the researchers. The reliability of the questionnaire was tested by using Cronbach's alpha and found to be .821 . As a result, it was found that third year ELT teacher trainees have mildly positive attitudes on environmental education. In addition, there were no statistically significant differences among the participants' sex and their membership at environmental organizations on their attitudes towards environmental education and their tendency to use them in language education. The result of this study is significant for numerous stakeholders, including teacher education programs, Ministry of Education, state leaders and surrounding communities and families of English language learners in relation with the efforts to integrate environmental education to the ELT curriculum.
\end{abstract}

Keywords: Environmental Education; ELT Teacher Trainees; Global Issues in Language Education

\section{INTRODUCTION}

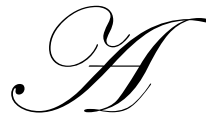

responsibilities.

Grammar-based, rule-governed approaches yielded to contextual language instruction where it becomes possible for learners to interact, share ideas, develop language and social skills as well as gain social and language awareness. This relatively recent movement towards socially responsible teaching (SRT) has encouraged language educators to use global issues as a context to develop language and social skills. Global education aims to "enable students effectively acquire a foreign language while empowering them with the knowledge skills and commitment required by world citizens to solve global problems" (Cates, 1990, p.41). From this broader perspective Global Issues in Language Education (GILE) covers many topics including peace education, environmental education, development education, and human rights education" (Peaty, 2004, p. 15). 


\section{Environmental Education}

Global issues and their use in foreign language teaching are considered very relevant as newer approaches examine the learners within their social and natural environments (Arıkan, 2009). A language can be learnt when it's presented in a meaningful context (Sağlam \& Gürsoy, 2010). Thus, SRT aims at helping students to focus on global issues by guiding classroom interaction towards social awareness in world problems (Arıkan, 2009).

Being one of the most prominent global issues, environmental education and its integration to foreign language learning has taken attention of many researchers (see, Gürsoy, 2010; Erten, 2004; Jacobs, Goatly, \& Ming, 1995; Karn, 2007; Cates, 1997). During the last century our world has witnessed the damage of environment due to the rapid scientific and technological developments (Gürsoy, 2010). As the human beings continue destroying the environment, the alarming consequences of these destructions have taken the attention of many people. Although problems such as global warming, ozone depletion and/or pollution scared the whole world, counter efforts to protect our world and energy resources were not effective enough, which indicated the low amount of participation in solving environmental problems. According to the United Nations's objectives on environmental education (UNESCO-UNEP, 1976 cited in Jacobs \& Goatly, 2000) awareness and understanding of the environmental problems are only the initial stages, which should be followed by developing an attitude of concern, skills to overcome such problems, ability to evaluate possible solutions and most importantly participating to the efforts to solve environmental problems. Hence, environmental education aims at helping learners to develop positive attitudes towards environmental protection by helping them change their behavior and guiding them to participate actively in the solutions (Şimşekli, 2004; Erten, 2004). Ünal \& Dımışkı, (1999) argue that the most important factor in reaching the goals of environmental education is "the teachers". The final remarks of the Tbilisi Conference in 1977 point out the need to fill the gaps in education systems. Thus, it invites educators to think, research, and bring in innovative approaches to environmental education (Ünal \& Dımıskı, 1999). Two of the principles of the environmental education according to Tbilisi declaration (1977) serve as a trigger to current research. Accordingly, environmental education should start from pre-school and cover formal and non-formal education and considered as a lifelong process. Secondly, it should be carried on holistically with an interdisciplinary approach by bringing together the relevant aspects of each discipline in a balanced manner.

The emphasis on sustainability in the Tbilisi Declaration could be managed by raising more aware and responsible world citizens. To enhance sustainability in education, teacher education institutions are considered as the key in changing the society (UNESCO, 2010). Therefore, teacher education institutions have great responsibility in training prospective teachers so as to help them develop socially responsible behavior and abilities to integrate environmental education with their disciplines. Unfortunately, the majority of studies on teacher education concerned science and biology fields and their teacher trainees (Sağlam \& Gürsoy, 2010). This indicates that environmental education is viewed as the responsibility of these respected fields. However, according to Tbilisi declaration it should be interdisciplinary. Teacher trainees' awareness and knowledge is an important factor in providing such and education in their future profession, as they can influence students' attitudes, views, and interaction with the environment (McKeown \& Hopkins, 2002 cited in Yavetz et al. 2009). Thus, the current study aims at investigating third year ELT teacher trainees' attitudes towards environmental education and their tendency to use such environmental issues when they graduate as teachers.

\section{METHODOLOGY}

The current study is the second phase of a two-phase study. Hence, only the results of the second phase will be discussed.The first phase aimed at investigating ELT (English Language Teaching) teacher trainees' awareness on environmental issues and the second phase aimed at investigating the attitudes of ELT trainees towards environmental education and their tendency to implement environmental education in their lessons. There are four research questions of the study:

1. What are the attitudes of third year ELT teacher trainees' towards environmental education?

2. Are there any gender differences in terms of trainees' attitudes?

3. Are there any differences between trainees who are a member of an environmental organization and who are non-members?

4. Do third year ELT trainees' have a tendency to implement environmental education in their lessons? 


\section{Participants}

224 third year ELT teacher trainees at Uludağ University in Bursa, Turkey contributed to the study. $71.9 \%$ of the participants were female and $25 \%$ were male. However, $3.1 \%$ did not indicate their gender. The imbalance between the genders is due to the general population of the ELT Department. Females constitute the majority of the population in the department. In addition, only $7.6 \%$ of the participants indicated that they are a member of an environmental organization. Thus, these factors need to be taken into consideration when interpreting the results and be considered as the limitations of the study.

\section{Instruments}

To identify trainees' attitudes towards environmental education and their tendency to implement environmental education in ELT lessons the researchers have conducted a questionnaire, which consists of 18 items on the basis of five-point Likert scale from strongly disagree to strongly agree. Each item was ranked as (0-1) strongly negative, (1-2) mildly negative, (2-3) neutral, (3-4) mildly positive, and (4-5) strongly positive. In this 18item questionnaire as each "strongly disagree" response corresponds to 1 point and each "strongly agree" response corresponds to five points. Thus, the maximum points that could be received from the questionnaire is 90 and the minimum point could be 18. As the "no idea" response is three points, points between 57 and 95 is interpreted as the increasing positive attitudes towards environmental education.

For the validation of the questionnaire, it was given to six teacher trainers in the ELT Department for their expert opinion. Trainers' feedback on the questionnaire was used to improve the instrument. Next, the revised and content validated questionnaire was administered to 20 third-year teacher trainees as a pilot study. The final form of the questionnaire is constructed upon the results obtained from the pilot study.

\section{Data Analysis}

For the reliability of the instrument Cronbach's Alpha test was used and found to be .821 , which indicates a moderately high reliability. In addition, t-test was used to identify the differences among gender groups and trainees' that have or do not have a membership to environmental organizations. Frequency analysis was made to find out trainees' tendencies towards the implementation of environmental education in foreign language lessons when they graduate.

\section{RESULTS}

The results of the study indicated that the participants have mildly positive attitudes towards environmental education with a mean of 64.7. As the maximum points that could be gathered from the questionnaire is 90 this result can be interpreted as trainees having relatively increased positive attitudes.

The t-test results indicated that there are no statistically significant differences between the genders of the participants nor there are differences between member and non-member participants to environmental organizations (table 1). Although one would expect that there might be differences among member and non-member participants, very low number (17 trainees, $7.6 \%$ ) of member participants should be kept in mind when interpreting the results. Yet, this by itself is prominent since this is an indication that the teacher trainees' are not actively taking part in the solution of environmental issues. According to UNESCO-UNEP's (1976 cited in Jacobs \& Goatly, 2000) environmental objectives, awareness about environmental problems is the initial step, which should then turn into taking action in solving those problems. Thus, the result indicates that teacher trainees' need help and instruction in how to take part in developing skills to solve environmental problems and participating to the efforts to solve them. 
Table 1

The influence of gender and membership to environmental organizations on trainees' attitudes

\begin{tabular}{|lcccc|}
\hline & N & Mean & SD & Statistics \\
\hline Gender & & & & $\mathrm{t}=.060$ \\
female & 161 & 65.16 & 5.2 & \\
male & 55 & 63.61 & 5.1 & \\
total & 216 & 64.7 & 5.2 & $\mathrm{t}=.169$ \\
\hline Membership & & & 5.03 & \\
member & 17 & 65.05 & 5.30 & \\
Non-member & 204 & 64.83 & 5.2 & \\
Total & 221 & 64.8 & & \\
\hline
\end{tabular}

The results of the frequency analysis are important since they indicate trainees' strong tendency to implement environmental education to the content of foreign language lessons. The majority of the participants (91.5\%) indicated that environmental education is the responsibility of every teacher regardless of their course (math, science, language...). This response is supported by another item at which they stated (71.9\%) that environmental topics should be covered within the content of all the courses in the curriculum. Unlike the general tendency around the world where the environmental education is covered in science and biology lessons, a high number of participants $(72.7 \%)$ disagreed with the idea to present environmental problems in science lessons. These results are important so that they show trainees' raised awareness about the issue and that as prospective language teachers they feel responsible for the teaching of environmental issues. However, only about half of the participants $(53.2 \%)$ felt they possess necessary knowledge and information to protect the environment. Likewise, less than half of the participants $(48.6 \%)$ indicated that they do not feel adequate in providing environmental education. The response was supported with $85.7 \%$ of the trainees' by stating that they would like to be informed and learn about environmental education. The result has serious implications so as to develop teacher training towards socially responsible teaching (SRT).

Membership to environmental organizations can be considered as an indication for higher awareness on environmental issues. $66.5 \%$ indicated that all teachers should be a member of environmental organizations, but in contrast $23.2 \%$ said that not every course teacher should be a member of environmental organizations. Although this is difficult to interpret, it can be inferred that the trainees' awareness on such organizations and their role at environmental problems are vague. Another response strengthens this interpretation when less than half of the participants (48.7\%) claimed that they are aware of the governmental and non-governmental environmental organizations. Moreover, considering the fact that only $7.6 \%$ of the participants are a member of such organizations, inadequate understanding of the roles and functions of governmental and non-governmental environmental organizations could have an effect on these results. This limited awareness points out the importance of collaboration of teacher education institutions with environmental organizations.

Being a prospective teacher it can be claimed that they are highly sensitive to environmental problems and feel responsibility to solve them. Almost all of the trainees (95.5\%) stated that environmental education should be provided systematically starting from kindergarten. This line of thought is very encouraging and consistent with the results of the Tbilisi Conference (1977). Moreover, by admitting that environmental education is the responsibility of all teachers (91.5\%), they feel that language teachers, as well, need to be a part of this. Similarly, $93.7 \%$ thinks that they need to increase their awareness on environmental topics. These results are pleasing in terms of teacher trainees' feeling of responsibility.

As to the participants' tendency to use environmental topics in foreign language education most of them (85.7\%) stated that environmental education is the responsibility of an English teacher and that they would like to $(88.9 \%)$ associate foreign language education with environmental education. More importantly, almost all of them (94.6\%) wanted to learn how this could be done as they believe $(89.7 \%)$ that environmental education can be provided while teaching a foreign language.

In terms of the role of the family in providing a good model to bring up environmentally responsible citizens $69 \%$ claimed that their families are sensitive towards the environment and $61.2 \%$ stated that they gained their environmental awareness and sensitivity from their families. 


\section{CONCLUSIONS AND IMPLICATIONS}

Because global issues and their use in foreign language teaching is considered very relevant as newer approaches examine the learners within their social and natural environments (Arıkan, 2009), teacher education and teacher education institutions' role in providing SRT is under scrutiny. Although Turkey has started its efforts in the 1960s almost simultaneously with the rest of the world with the inclusion of the importance of people's mental and physical health in its 1961 constitution (Özdemir, 2003) and continued with increased attention to the environment which was reflected in the school curriculum (Gürsoy, 2010) and despite the projects developed by the governmental and non-governmental environmental organizations, the experts at the 4th Environmental Council organized by the Ministry of Environment emphasized that the environmental education is still inadequate in Turkey (Şimşekli, 2001). The expert opinion in the inadequacy of environmental education points fingers at teacher education. It is claimed that teacher education posses the key to develop environmentally literate citizens (UNESCO, 2010; McKeown and Hopkins, 2002, cited in Yavetz et al., 2009) as teachers can influence learners to raise their awareness on environmental issues, develop positive attitudes towards the environment and show them how to become environmentally responsible citizens.

Unfortunately, studies on teacher education report that prospective teachers do not possess the necessary knowledge nor have they positive views on environmental policies and programs (see, Waktola, 2009). In addition, teacher training process does not prepare teacher trainees with adequate environmental knowledge (see, Yavetz, Goldman, and Pe'er, 2009). Current study supports these results in the literature as less than half of the participants think that they possess the necessary and adequate knowledge to provide environmental education.

The results of the present study are important since they indicate the willingness of prospective teachers to learn about environmental education, and how to implement it within their courses. Moreover, it can be interpreted from the results that the participants have a tendency to integrate environmental education in their course if necessary education is provided during teacher training.

The results also show that the participants consider themselves responsible in providing environmental education. Within the context of SRT not only environmental issues, but also global issues in general, needs to be integrated in teacher education. Especially methodology courses can be used to provide such information as well as providing trainees with the necessary skills to implement global issues in their lesson plans.

The study is unique as it aims to scrutinize teacher education process by focusing on ELT teacher trainees. However, this could only be an initial step to investigate the implementation of environmental topics to other courses in the curriculum. Therefore, further research is necessary to investigate teacher trainees' attitudes in respective departments as well. In addition, curricula at the teacher education institutions need to be analyzed to identify ways to integrate environmental education in teacher training.

The small number of trainees, who are member of environmental organizations, serves as a trigger for similar research to find out the underlying reasons related to this fact. As this indicates that although prospective teachers are willing to learn about environmental education and use it in their future classes they are not actively participating in the efforts to protect the world. As environmental issues are global and cannot be considered as the problem of individual countries, educators around the world should work together to improve teacher education in this respect.

\section{AUTHOR INFORMATION}

Esim Gürsoy is an assistant professor in the ELT Department of Uludağ University, Turkey. She holds an M.Ed from the Teacher Education Department and a TEFL certificate from the Lingusitics Department at Ohio University, USA and a Ph.D from Anadolu University, Turkey. She is currently teaching at the graduate and undergraduate level at Uludağ University. She has published articles related to topics on teacher education, foreign language teaching to young learners, integration of environmental issues to foreign language classes, and CALL. Her research interests are teacher education, foreign language teaching to young learners, language learning strategies, and global issues in ELT. E-mail: esimgursoy@yahoo.com 
Dr.Gülderen Sağlam was graduated from ELT department at Uludağ University. She had her M.A on TEFL at Bilkent University in Turkey. Later, she continued her education at the University of Leeds in England, and completed her PhD. at METU. She is enthusiastically interested in teacher training, and would like to work with teachers in the following years. Global issues, democracy in education, creating meaningful environments and contributing to teachers' lives to become socially responsible teachers are some of her challenging content areas in teacher education. At present, she is working as a lecturer and a teacher trainer at Uludağ University. E-mail: gulderentt@hotmail.com

\section{REFERENCES}

1. Arıkan, A. (2009). Environmental peace education in foreign language learners' English grammar lessons. Journal of Peace Education, 6, (1), 87-99.

2. Cates, K. A. (1997). New trends in global issues and English teaching. The Language Teacher Online,21, (05).

3. Cates, K. A. (1990). Teaching for a better world: Global issues and language education. The Language Teacher, 41-52.

4. Erten, S (2004). Çevre eğitimi ve çevre bilinci nedir, çevre eğitimi nasıl olmalıdır? [What is environmental education and environmental awareness, how should environmental education be done?] Çevre ve Insan Dergisi, 65.

5. Gürsoy, E. (2010). Implementing environmental education to foreign language teaching to young learners. Educational Research, 1, (8), 232-238.

6. Jacobs, G. M. and Goatly, A., (2000). The treatment of ecological issues in ELT coursebooks. ELT Journal, 54, (3), 256-264.

7. Jacobs, G. M., Goatly, A., and Ming, J. (1995). Language and the environment. PASAA,25, 54-63.

8. Karn, S. K. (2007). Current trends in ELT around the globe. Journal of NELTA, 12, (1\&2), 60-66.

9. Özdemir I (2003). The development of environmental consciousness in modern Turkey. In R. Foltz, (Ed.) Environmentalism in the Muslim world, (pp. 1-23). Boston: MIT Press.

10. Peaty, D. (2004). Global issues in EFL: Education or indoctrination? The Language Teacher, 28, (8), 15-18.

11. Sağlam, G.T. and Gürsoy, E. (2010). Elt teacher trainees' awareness on environmental issues and their integration to the curriculum. Proceedings from ICONTE-International Conference on New Trends in Education and Their Implications, 11-13 Nov., 2010, Antalya , Turkey.

12. Şimşekli Y (2001). Bursa'da "Uygulamalı çevre eğitimi”" projesine seçilen okullarda yapılan etkinliklerin okul yöneticisi ve görevli öğretmenlerin katkısı yönünden değerlendirilmesi. Uludağ University Journal of the Faculty of Education 14, (1):73-84.

13. Şimşekli, Y. (2004). Çevre bilincinin gelişmesine yönelik çevre eğitimi etkinliklerine ilköğretim okullarının duyarlılığı. Uludag University Journal of the Faculty of Education, 17, (1), 83-92.

14. Tbilisi Conference, (1997). Intergovernmental Conference on Environmental Education. Organized by UNESCO in cooperation with UNEP. Retrieved from http://www.gdrc.org/uem/ee/EE-Tbilisi_1977.pdf

15. UNESCO (2010). Retrieved on Aug.12, 2010 from http://www.unesco.org/en/esd/networks/teachereducation

16. Ünal, and Dımışkı, (1999). UNESCO-UNEP himayesinde çevre eğitiminin gelişimi ve Türkiye'de ortaöğretim çevre eğitimi. Hacettepe University Journal of the Faculty of Education, 16, (17), 142-154.

17. Waktola, D. K. 2009. Challenges and opportunities in mainstreaming environmental education into the curricula of teachers' colleges in Ethiopia. Environmental Education Research, 15, (5), 589-605.

18. Yavetz, B., Goldman, D., and Pe'er, S. (2009). Environmental literacy of pre-service teachers in Israel: A comparison between students at the onset and end of their studies. Environmental Education Research, 15, (4), 393-415. 